\title{
Withdrawal of patent claim leaves position of plants unclarified
}

\begin{abstract}
Munich. The European Patent Office (EPO) was last week deprived of the opportunity to reassess its current $d e$ facto moratorium on the patenting of plants, after the withdrawal of claims to a patent that had been issued to Lubrizol Corporation of the United States in 1989, which had been challenged by environmentalist protesters.
\end{abstract}

The Lubrizol patent covered any transgenic plant that had been originally derived from a plant cell transfected with a plant gene under the control of a plant promoter, using a defined gene transfer system.

Officials at the EPO had hoped that the challenge to the patent would be referred by its lower appeals board to its Enlarged Board of Appeals, the office's highest legal authority, which might then reverse a decision made last year - and confirmed by the Enlarged Board of Appeals in December - that plants are in principle not patentable (see Nature 374, 8; 1995).

The latter decision concerned a patent that had been granted to the Belgian company Plant Genetics Systems (PGS). It was based on article 53(b) of the European Patent Convention - the EPO's rule book - which explicitly excludes plant varieties from patentability. The appeal board was persuaded by opposition arguments that plants can be considered as constituting plant varieties, and are therefore not patentable.

Following this verdict, whose implications are of major concern to the biotechnology industry, the EPO has not issued any further patents on plants or animals this year. Officials had hoped that a clear verdict in the Lubrizol case would allow them to ask the Enlarged Board of Appeals specifically to clarify the scope of the exclusion article, and therefore perhaps to allow them to lift the moratorium.

But Lubrizol will not after all provide a test case for the patent office. During a hearing on the challenge last week - and before opposition to the patent on the basis of article 53(b) had been heard the company announced that it was abandoning claims in its patent to the plants and plant cells arising from its transfection procedure.

Lubrizol Corporation said that it was doing this because it could not defend itself against the more conventional criticism of the patent claim that it did not include the required inventive step .

Alison Abbott

\section{Death of molecular biologist stuns San Diego science}

San Diego. A prominent Japanese scientist engaged in research into Alzheimer's disease at the University of California at San Diego (UCSD) was murdered virtually on his doorstep on 7 May, sending shockwaves through the city's academic and biotechnology communities.

Tsunao Saitoh, 47, was shot several times in the head as he was returning to his home in the wealthy community of La Jolla. His 13-year-old daughter Loullie, who was wearing a lab coat that may have made her a target, was also shot several times in the attack, shortly before midnight.

Police in San Diego say that they remain baffled over the motivation behind the two murders. Saitoh was known for working 12hour days in pursuit of a gene expressing a protein that, he believed, was intimately involved in the process by which beta amyloid destroys neurons and causes Alzheimer's disease.

The cold-blooded manner in which Saitoh and his daughter were killed has prompted speculation about whether pressures in the scientific community in San Diego, where many fortunes have been made on the back of the growth of the biotechnology industry, may have contributed to the incident.

In particular, questions have been raised over whether Saitoh's death was related to the race currently taking place to conquer Alzheimer's disease, which in America alone afflicts more than four million people. Some researchers have rejected as implausible the idea that Saitoh's research could be related to his murder. But others point out that violent incidents have, in the past, grown out of personal differences within the research community.

Some years ago, for example, one $\mathrm{La}$ Jolla scientist unsuccessfully attempted to poison another after a conflict developed between the two over a research project. A biotechnology venture capitalist points out that fights over patent rights are sometimes known to have become particularly vicious.

Even murder is not unknown. Several years ago, a woman who had testified in court in a patent fight in the San Francisco area was later found strangled, leading to speculation that the murder might have been linked to industrial espionage.

Some laboratories at San Diego institutes are known for their intense competition, with laboratory notebooks disappearing from unsecured lockers, researchers afraid to discuss discoveries at conferences, and the rights to discoveries being misappropriated for the development of biological products.

But the UCSD Alzheimer's Disease
Research Center — which operates under a \$14 million grant from the National Institutes of Health (NIH), and where Saitoh conducted his research - does not have a reputation for such aggressive antics.

Saitoh had been at UCSD for nearly a dozen years, using molecular biology to seek the genetic source of beta amyloid's destructive course in the brain. In addition to the $\mathrm{NIH}$ funding, he is said to have also received about $\$ 100,000$ a year from the National Alzheimer's Association and a private foundation. He also may have had ties to some biotechnology or pharmaceutical firms.

Saitoh received his doctorate at the University of Kyoto in Japan. Prior to being appointed to his research post in San Diego in 1985, he had carried out research at Columbia University in New York and at the Pasteur Institute in Paris.

During his time in San Diego, he made his mark as a brilliant researcher known also for his teaching skills with young scientists. But acquaintances say that he was discrete about his personal life.

In 1995 , he purchased an $\$ 800,000$ home near an exclusive private golf club in the heart of the seaside village of La Jolla. He also owned two condominiums in the region. He is estranged from his wife, who was in Europe at the time of the murders. But they reportedly lived in and owned the La Jolla home together.

According to police, at the time of the shooting, Saitoh and his daughter were returning home from his laboratory after working on a school project for the girl. Saitoh was killed at the wheel of his BMW car, while the girl was found some distance away lying on the driveway, indicating that she had been trying to escape when shot in the back and head.

Analysis later revealed that both victims had been struck by shots from a smallcalibre handgun. Saitoh's daughter was hit from a distance of about 30 feet, suggesting that the shooting may have been carried out by a professional killer.

In addition to investigating Saitoh's murder, law enforcement authorities in San Diego are also preparing to put on trial a Pennsylvania man involved in an earlier scientist killing, the murder last December of British geophysicist Stanley Runcorn (see Nature 378, 657; 1995).

A well-respected scientific figure and a professor at the University of Alaska, Runcorn had been visiting friends in California when he was murdered in a hotel room. Paul B. Cain, a 24-year-old kickboxer who had evaded US authorities for several months by hiding in Mexico, has now been charged with the crime.

Rex Dalton 